\title{
Analysis of Effect of Financing Leverage on Bank Performance: Evidence from Nigeria
}

\author{
Ebiringa, Oforegbunam Thaddeus. (Ph.D) (Corresponding Author) \\ School of Management Technology, Federal University of Technology \\ Owerri-Nigeria \\ Email: otebiringa@yahoo.com \\ Ezeji, E. Chigbu (Ph.D) \\ School of Management Technology, Federal University of Technology \\ Owerri-Nigeria
}

Received:November 03, 2012 Accepted:December 28, 2012 DOI:10.5296/jpag.v2i4.3036

\begin{abstract}
This paper analyzes the effect of leverage financing on corporate performance using debt-equity, coverage ratios and earnings per share as proxies. The study is motivated by need to assess the extent to which leverage affects optimizes financing risk as well as maximize returns to shareholders in the Nigerian banking industry. The study made use of F-ratios, Durbin-Watson, Akaikeand Schwarz Information Criteria as well as to log likelihood parameters in arriving at conclusions. Though the results across banks studied shows mixed outcome, leverage financing was established as critical strategy for maximization of shareholders returns. The conclusion therefore is that in order to ensure that leverage financing leads to desired outcome business organisations must established their optimum level as well as strike a strategic balance with associated financing risk and returns to owners of the firm.
\end{abstract}

Keywords: Money, Interest rate, volatility, endogenous, spread, integration, intermediation 


\section{Introduction}

In the quest to optimize their objective, which hinges primarily on quantifiable performance, financial managers have adopted various capital structures as a means to that goal. A firm can finance its investment by debt and/or equity. The use of fixed-charged funds,) such as debt and preference capital along with the owner's equity in the capital structure is described as financial leverage or gearing (Dare and Sola, 2010). An unlevered firm is an all-equity firm, whereas a levered firm is made up of ownership equity and debt. Financial leverage takes the form of a loan or other borrowing (debt), the proceeds of which are (re)invested with the intent to earn a greater rate of return than the cost of interest. If the firm's marginal rate of return on asset (ROA) is higher than the rate of interest payable on the loan, then its overall return on equity (ROE) will be higher than if it did not borrow (Laurent, 2005). On the other hand, if the firm's return on assets (ROA) is lower than the interest rate, then its return on equity (ROE) will be lower than if it did not borrow. Leverage allows a greater potential returns to the investor than otherwise would have been available, but the potential loss is also greater: if the investment becomes worthless, the loan principal and all accrued interest on the loan still need to be repaid (Andy et al, 2002). This constitutes financial risk (Pandey; 2005). The degree of this financial risk is related to the firm's financial structure.

The total combination of common equity, preferred stock and short and long term liabilities is referred to as financial structure. That is, the manner in which the firm finances its assets constitutes its financial structure. If short-term liabilities are subtracted from the firm's financial structure, we obtain its capital structure. In other words, the firm's permanent or long-term financing consisting of common equity, preferred stock and long term debt is called capital structure (Van Horne; 2002). Hence, the objective of financial management in structuring a firm's capital components is to maximize the shareholders' wealth, as a measure of performance.

Based on the above the problem of this study is to analyse the implications of financial leverage on performance. Also considering that maximizing accounting profit and maximizing shareholders' value are not identical because of shareholders' losses from agency costs, it is therefore pertinent to see how capital structure affect shareholders' value.

A survey of the empirical literature on this debate shows lack of consensus on the link between leverage and corporate performance. Scholars of Modigliani-Miller theorem insists that leverage should not affect the expected overall return. On another side of the divide is the expansionist that posits that most performing firms ask for more debt, implying: there should be a positive relation between corporate performance and leverage. A third group posits that "asset-substitution" and "underinvestment", as a result of conflict of interest between shareholders, managers and debt holders suggest that a higher leverage is correlated with a lower performance. These divergent claims form the basis of this paper which considers if corporate performance is significantly affected by financing leverage and how.

\section{Study Objective, Scope \& Significance}

In relation to the problems stated above, the central objective of this paper is to analyze the 
effect of financial leverage on corporate performance as well as to determine when the shareholder's wealth can be said to have been maximized given a particular capital structure. In carrying out this study, a number of relevant questions come to mind.

- To what extent does capital structure affect shareholders' returns?

- Is there evidence to suggest that the effect of leverage on shareholders return is consistent across firms in same industry?

To this extent the following hypotheses serve as a guide for our analysis:

- Debt equity ratio does not have significant effect on earnings per share of banks.

- Interest coverage does not have significant effect on earnings per share of banks.

- Financial leverage does not have a similar effect on the corporate performance of firms in the Nigerian banking industry.

The population of this is the Nigerian banking industry. A simple random sample of six (6) banks based on five (5) year financial aggregates was used for the analysis. The above tend to have limited the extent to which the any inference drawn based on the findings can be applied to other industries.

\section{Theoretical Framework}

A particular combination of common stock, preferred stock and debt used in financing the assets of a firm creates some level of financial risk. Financial risk is directly related to the firm's capital and financial structure/leverage (Pandey, 2005). The primary motive of a firm in using financial leverage is to increase shareholders' return under favourable economic conditions. Financial leverage will enhance shareholders' return on the condition that fixed charge funds (such as long term loans from financial institutions and other sources) can be obtained at a cost lower than the firm's rate of return on net assets (RONA or ROI). Where the difference between the earnings generated by assets financed by fixed charge debt funds and costs of these funds are distributed to shareholders, the earnings per share (EPS) or return on equity (ROE) increases. EPS or ROE will fall if the firm obtains fixed charge debt funds at a cost higher than the rate of return on the firm's assets. Therefore, EPS and ROE are important aggregates for analyzing the impact of financial leverage on a firm (Pandey; 2005).

Fixed costs are cash outflow that occur regardless of whether the asset is active or idle. Favourable leverage is a situation in which EPS rises as a result of introduction of debt into the capital structure. Unfavourable leverage is a situation in which EPS falls as a result of debt introduced into the capital structure. The level of financial leverage is a change in EPS caused by the use of long term debt to finance a firm's operation, which exposes the firm to business risk and financial risk that may impact on the performance of the firm negatively. Business risk depends on the industry to which a firm operates and on general economic conditions. Financial risk is the additional variability of earnings often induced by leverage. The impact of financial leverage on firm performance given the assumption that uncertainty prevails, can be reduced according to Ikpefan and Enahoro(2007) through three alternatives: 
- Situation in which leverage decreases risk, but at the same time decreases expected EPS.

- Neutral situation in which the increase in risk following the introduction of leverage leaves EPS unchanged.

- Situation in which the introduction of leverage increases expected EPS and risk simultaneously.

Keown et al (2003) opined that financial structure is the mix of all items that appear on the right hand side of the company's balance sheet. Capital structure is the mix of the long-term sources of funds used by the firm (Van Horne 2002). Therefore, financial structure is the sum of current liabilities and capital structure. The assets owned by the firm affect the maturity profile of financial plans. A firm heavily committed to real capital investment, represented primarily by fixed assets on its balance sheet, should finance those assets with permanent (long-term) types of capital. Permanent portion of the firm's investment in current assets should likewise be financed with permanent capital. The firm's cost of equity rises when the firm increases its use of financial leverage because the financial risk of the equity increases while the business risk remains the same (Westerfield and Ross;2000). The total systematic risk of the firm's equity has two parts: business risk and financial risk. The first part (the business risk) depends on the firm's assets and operations and is not affected by capital structure. Given the firm's business risk (and its cost of debt), the second part (financial risk) is completely determined by financial policy (Ikpefan and Enahoro; 2007).

A major issue in corporate governance literature is the influence of financial leverage on corporate performance. Two motivations underline the interest on this. On one hand, this issue has some public policy considerations because of its implications on the policies promoting fairness and equity among fund providers. On the other hand, a positive relation between financial leverage and corporate performance would mean that inter-company differences in access to credit result in competitive advantages. Lane (2009) agrees that a firm's financing structure may affect its incentive to generate profit and invest. Therefore, it may determine strategic interactions between the firm's capital structure choice and the behaviour vis-à-vis its customers, suppliers and competitors. Since the use of debt financing can lead to some economic benefits, firms with less plastic asset could have higher financial leverage than firms with more plastics asset (Iwarere and Akinleye; 2010).

In line with the above firms that enter into a long-term contractual relationship with their customers, create an implicit expectation of sustained flow of supply at non-trivial switching costs. A firm providing such type of goods or services may incur a demand decline for their products if it leverages up its capital structure and such behaviour is perceived by customers as potentially harmful and an indication of the firm's likelihood of bankruptcy (Hovakimian et al. 2001). Firms with investment in reputable business and guaranteed product quality will employ lower financial leverage. By implication, an increase in the incentive for firm to depreciate quality as a consequence of higher leverage is likely to cause a decline in the value of reputation.

This impact is important based on the binding role of debt; debt financing raises the pressure 
on managers to perform, because it reduces the moral hazard behaviour by reducing 'free cash-flow' at the disposal of managers. Consequently, firms with higher leverage should be the most incited to improve their performance. On the other hand, a higher leverage means higher financing costs. This suggests that leverage may be negative linked to performance. If capital structure definition and readjustment do matter, it follows then that such decisions are not random as implied by Modigliani and Miller (1958) and that decision makers at the firms level may arguably adopt a policy model to guide their choices. Firms choose their mix of debt and equity by trading off expected costs and benefits of debt financing. The theory describes a firm's optimal capital structure as the mix of financing that equates the marginal costs and benefits of debt financing. A major empirical prediction of this trade-off theory is that debt ratios will tend to be meaning reverting as firms use external capital markets to keep themselves at or close to their optimum debt levels. Trade-off theories however, leave undetermined its underlying economic framework and the identification and measurement of costs and benefits. Among the benefits included in the trade-off equation is the tax shield/advantages of debt financing and the benefits associated with the control of free cash flow.

Capital structure can help to mitigate the inefficiencies in a firm's investment programme that are caused by information asymmetries. This results in an interaction between investment and financing decisions. Because market participants cannot separate information about new project from information about whether the firm is undervalued or overvalued, market participants will misprice equity. It firms are required to finance new project by issuing equity, under-pricing may be so severe that new investors capture more than the net present value of the new project which would result in a net loss to existing shareholders. Even, a positive net present value project will be rejected, leading to yet another investment problem. The information costs associated with debt and equity issues has led Myers (2001) to argue that a firm's capital structure reflects the accumulation of past financial requirements. There is a pecking order of corporate financing such that;

- Firms prefer internal finance;

- If internal finance is not sufficient and firms require external finance they issue the cheapest security first. In this case, they start with debt then possibly securities such as convertible bond and issue equity only as a last resort.

In contrast to the trade off theory, there is no well-defined target leverage ratio in the pecking order theory. There are two kinds of equity, internal and external. One is at the top of the pecking order and one at the bottom. Hence, as argued by Baker and Wurgler (2002), a firm's leverage ratio thus reflects its past cumulative requirement for external finance. Most importantly, the pecking order theory can explain why most profitable firms tend to borrow less; they simply do not need external funds. Less profitable firms issue debt because they do not have sufficient internal funds and because debt has lower floatation and information costs compared to equity. Debt is the first source of external finance on the pecking order. Equity is issued only as a last resort when the debt capacity is fully exhausted. Tax benefits of debt are a second order effect. The debt ratio changes when there is an imbalance between internal 


\section{I Macrothink}

funds and real investment opportunities (Myers and Lambrecht, 2007). Hence there is clearly no consensus on the relationship between financial leverage and corporate performance from empirical literature.

\section{Research Design}

This research is designed to collect data through the documentary method, which involves several issues of reports from various banks and the Nigerian Stock Exchange. Two basic approaches descriptive and analytical design were adopted. The descriptive design uses ratios/percentages to highlight the effect of financial leverage on corporate performance; while the analytical design assessed using a mathematical model the nature and significance of the effect of financial leverage on corporate performance. The population of study is the banks in the Nigerian banking industry. They are presently twenty-four (24) in number. The simple random sampling technique was used to select six (6) banks from the population. They are

- Zenith Bank PLC

- United Bank for Africa PLC

- Union Bank of Nigeria PLC

- Access Bank PLC

- Diamond Bank PLC

- Platinum Habib Bank PLC

The secondary data used for analysis were collected from the Nigerian Stock Exchange fact book and the financial statements of the various banks. These were the most viable sources available and of course, only secondary sources such as those mentioned above could suffice for the analysis by virtue of the nature of the variables. Regression analysis tool was employed to examine how significant financial leverage affects corporate performance. Here, we take debt-equity ratio and coverage ratio as the independent variables, while earning per share (EPS) representing performance is the dependent variable. Having identified the proxy for corporate performance as earnings per share (EPS), as well as the proxies for financial leverage as debt-equity ratio and coverage ratio, the model under study is presented thus;

Corporate performance $($ EPS $)=f($ financial leverage proxies $)$

Regression function: $\mathrm{EPS}=\mathrm{f}(\mathrm{D} / \mathrm{E}$ ratio, $\mathrm{EBIT} / \mathrm{INT}$ ratio $)$;

Therefore

$$
\text { EPS }=\alpha_{o}+\beta_{1} \text { D/E ratio }+\beta_{2} \text { EBIT/INT ratio }+e_{o}
$$

Where:

EPS = Earnings per share (Proxy for Corporate performance)

$\mathrm{D} / \mathrm{E}=$ Debt-equity ratio; $\mathrm{EBIT} / \mathrm{INT}=$ Earning Before Interest and Tax/Interest 
Ratio(Coverage ratio).

$\alpha_{\mathrm{o}}, \beta_{1}$ and $\beta_{2}$ parameter to be estimated and $\mathrm{e}_{\mathrm{o}}$ is the error term.

\section{Results and Discussions}

The models for analysing the effect of financing leverage on the performances of the sampled banks are as specified in equations 1-6.

Table 1: Summary of Results

\begin{tabular}{|c|c|c|c|c|c|c|c|c|c|}
\hline Bank & R-Sqd & F-stat & $\begin{array}{c}\text { Prob. } \\
\text { (F-stat) }\end{array}$ & DW stat & $\begin{array}{r}\text { t-stat o } \\
\text { In } \\
\text { EB }\end{array}$ & $\begin{array}{l}\text { everage } \\
\text { ces } \\
\text { E } \\
\text { /INT }\end{array}$ & AIC & SIC & $\begin{array}{l}\text { Log } \\
\text { likelihood }\end{array}$ \\
\hline Zenith & 0.4824 & 0.9320 & 0.5176 & 1.8938 & -1.22467 & 1.3357 & 1.365 & 1.130 & -0.412 \\
\hline UBA & 0.7000 & 2.3330 & 0.3000 & 1.7007 & -1.98934 & -0.33409 & 1.831 & 1.597 & -1.576 \\
\hline UBN & 0.5645 & 1.2964 & 0.4355 & 0.6797 & 0.549361 & 0.796089 & 1.673 & 1.439 & -1.183 \\
\hline Access & 0.9434 & 16.6569 & 0.0566 & 2.6908 & -3.82791 & 5.538348 & 0.359 & 0.125 & 2.103 \\
\hline Diamond & 0.8697 & 6.6743 & 0.1303 & 2.9718 & -3.65026 & 0.249761 & 0.247 & 0.012 & 2.384 \\
\hline PHB & 0.7557 & 3.0934 & 0.2443 & 2.6633 & 0.805303 & 2.318130 & 2.736 & 2.501 & -3.839 \\
\hline
\end{tabular}

DW: Durbin-Watson; AIC: Akaike Information Criterion; SIC: Schwarz Information Criterion

Source: Result of Computer Analysis with Eviews 6.0

Zenith bank Plc's leverage financing level led to 48.42 percent overall effects on her corporate performance. At $10 \%$ level, her debt/equity level had insignificant negative effect, while her coverage level had positive effect, though insignificant. The Durbin-Watson statistic of 1.894, (less than 2) suggest the existence of positive serial correlation in annual returns to shareholders due to the existence of financial leverage in her capital structure.Equation 1 shows that the likelihood effect of growth in leverage in the financing structure of Zenith Bank for the period 2005-2009, in a negative return to shareholders (Log likelihood of EPS=-0.412). This may be due to the fact that the bank has surpassed her optimum leverage level which may have increased her overall financing risk.

Zenith Bank :

$E P S=-0.03-0.71 D / E+0.92 E B I T / I N T$.

1

United Bank for Africa Plc's leverage financing level led to 70.0 percent overall effects on her corporate performance. At $10 \%$ level, her debt/equity and coverage level had insignificant negative effect. However the Durbin-Watson statistic of 1.70 (less than 2), suggesting the existence of positive serial correlation in annual returns to shareholders due largely to increasing financing leverage. Equation 2 equally shows that the existences of leverage in the 
financing structure of has the likelihood of leading to negative returns to shareholders ( $\log$ likelihood of EPS=-1.576). The implication of the above may be that the bank has leverage level is above the optimum level which has the tendency of increasing the financing risk of the bank as well as endangering future returns to her shareholders.

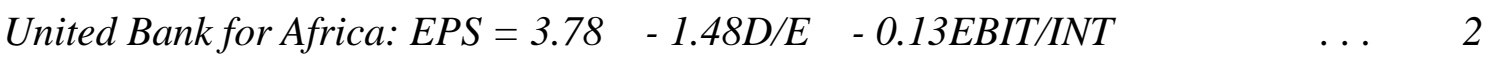

Union Bank Plc's leverage financing indicate 56.45 percent overall effects on her corporate performance. At $10 \%$ level, her debt/equity and coverage level had insignificant positive effect. However the Durbin-Watson statistic of 0.6997, which is less than 2, suggesting the existence of positive serial correlation in annual returns to shareholders due to the use of leverage financing. Equation 3 further shows that increased leverage in the financing structure has the long run effect of driving returns to shareholders towards negative (Log likelihood of EPS= -1.183). The implication being that the bank has surpassed its optimum leverage level to the extent that financing risk increased to disadvantage of shareholders.

Union Bank: $\quad E P S=-1.05+0.12 \mathrm{D} / E+1.04 E B I T / I N T \ldots 3$

Access Bank Plc's leverage financing indicate 94.34 percent overall effects on her corporate performance. At $10 \%$ level, her debt/equity level had significant negative; while coverage ratio has positive effects respectively. However, the Durbin-Watson statistic of 2.69 (greater than 2); suggesting the existence of negative serial correlation in yearly return to shareholders. Equation 4 shows that the management of Access bank has efficiently used leverage in her financing structure to the extent that the long run effect is positive returns to shareholders (Log likelihood of EPS =2.103). However, the existence of negative serial correlation further imply that the bank has a strategy of reducing her leverage level within an optimum level that ensures that financing risk is not increased to the disadvantage of shareholders.

Access Bank: $\quad$ EPS $=-2.35-0.80 D / E \quad+2.20 E B I T / I N T \quad \ldots \quad 4$

Diamond Bank Plc's leverage financing indicate 94.34 percent overall effects on her corporate performance. At $10 \%$ level, her debt/equity level had significant negative effect while the coverage ratio had insignificant positive effects. The Durbin-Watson statistic of 2.69 (greater than 2), suggesting the existence of negative serial correlation in annual performance due to leverage financing. Equation 5 further shows that the financing structure of Diamond bank for the period is within optimum level of leverage to the extent that financing risk has been managed to the advantage of shareholders as long run effect is positive returns (Log likelihood of EPS= 2.384).

Diamond Bank : $\quad E P S=1.54-1.010 D / E+0.04 E B I T / I N T \ldots 5$ 


\section{Macrothink}

Platinum- Habib Bank Plc's leverage financing indicate 75.57 percent overall effects on her corporate performance. At $10 \%$ level, her debt/equity and coverage level had insignificant positive effects. However the Durbin-Watson statistic of 2.69, (greater than 2), suggesting the existence of negative serial correlation in returns to shareholders. Equation 6 shows that the banks has increased its leverage level above her optimum level to the extent that future returns to shareholders is at risk ( $\log$ likelihood of EPS $=-3.839)$.

$$
\text { Platinum- Habib: } \quad \text { EPS }=-7.76+1.42 D / E+3.99 E B I T / I N T \ldots 6 .
$$

\section{Conclusions}

Based on the results of the analysis and the discussions, the following conclusions are made:

All the sampled banks use leverage as a critical component of their financing structure.

Leverage is a critical option for diversifying financing risk.

$>$ Leverage has the probability of enhancing the performance of firms if well structured and managed.

$>$ The effect of leverage on performance of firms in same industry is mixed as it has negative effects on Union Bank, Zenith Bank, United Bank for African and Platinum-Habib bank, while having positive effects on Diamond Bank and Access Bank.

$>$ An optimum leverage level must be determined and maintained by individual firms in order to ensure that financing risk is not increased beyond acceptable limit, which will lead to lower returns to shareholders.

> Based on the Akaike and Schwarz criteria, Diamond Bank and Access Bank can be said to have had the most efficient leverage financing strategies as the model built using their financial statistics showed the least entropy (see AIC and SIC values) offering the least measure of the information lost when used to describe reality of the effect of financial leverage on firm performance. This is a relative measure of goodness of fit as exhibited by equations 4 and 5 as well describe the tradeoff between bias and variance in model construction, or loosely speaking that of accuracy and complexity of the models when compared with equations 1, 2, 3 and 6.

\section{Recommendation for further Research}

Based on the above conclusions there is need for further research using Equations 1 and 2 to further determine the optimum leverage levels which minimizes financing risk as well as maximise return to shareholders of the two banks. 


\section{Macrothink}

\section{References}

Andy, C. W. C, Chuck, C. Y. K. and Alison, E. L. (2002) "The Determination of Capital structure: Is national Culture a Missing Piece of the Puzzle?" Journal of International Business Studies.

Baker, M. and Wurgler, J. (2002), "Market Timing and Capital Structure."Journal of Finance, Vol. 57.

Dare, F. D, and Sola, O. (2010), "Capital Structure and Corporate Performance in Nigerian Petroleum Industry: Panel Data Analysis."Journal of Mathematics and Statistics, Science Publications.

Hovakimian, A., Opter, T. and Titman, S. (2001), "The Debt-Equity Choice.”Journal of Financial Quantitative Analysis, Vol. 36.

Ikpefan, O. A. and Enahoro, J. A. (2007), "Interface of Leverage and Earnings: An Investigation into the Nigerian Manufacturing Sector." The Nigerian Accountant, Vol. 64.

Iwarere, H. T. and Akinleye, G. T. (2010), "Capital Structure Determinants in the Nigerian Banking Industry: Financial Managers' Perspective." Pakistan Journal of Social Sciences, Vol. 7.

Keown, A. J., Martin, J. D., Petty, J. W and Scot, D. F. (2003), Foundation of Finance: Pearson Education Limited, New Jersey.

Lane, D. (2009), "The Cost of Capital, Corporation Finance and Theory of Investment: A Refinement." Applied Economic Letter Vol.16.

Laurent, W. (2005), "Leverage and Corporate Performance: A Frontier Efficiency Analysis." Journal of Mathematical Economics, Vol. 44.

Modigliani, F. and Miller, M. (1958), "The Costs of Capital, Corporate Finance, and the Theory of Investment."American Economic Review.Vol. 17.

Myers, S. C. (2001), “Capital Structure.”Journal of Economic Perspectives, Vol. 15.

Myers, S. C. and Lambrecht, B. M. (2007), "A Theory of Takeovers and Disinvestments".Journal of Finance, Vol. 62.

Pandey, I. M. (2005), Financial Management:Vikas Publishing House PVT Limited, New Delhi.

Van Horne, J.C. (2002), Financial Management and Policy, Prentice Hall of India Private Limited, New Delhi.

Westerfield, W. R. and Ross, A. S. (2000), Fundamentals of Corporate Finance: McGraw-hill Inc., New York. 